\title{
MANAJEMEN MUTU PENGEMBANGAN LEMBAGA PENDIDIKAN ISLAM
}

\author{
Nurul Yaqien', Ahmad Sholeh², Abdul Ghofur ${ }^{3}$ \\ 1,2,3 Universitas Islam Negeri Maulana Malik Ibrahim Malang \\ e-mail: ${ }^{1}$ nyaqien@mpi.uin-malang.ac.id, ${ }^{2}$ sholeh@pgmi.uin-malang.ac.id, \\ 3gafur@pgmi.uin-malang.ac.id
}

\begin{abstract}
Abstrack: A good quality institution is required to afford good quality and professional human resources (HR) services. It is expected that a good quality education process will be able to produce competitive human resources nationally, regionally, and globally. The indicators of a good quality Islamic education institution can be seen from the academic or non-academicals achievements and the accreditation grade at the national or international level. This study aims to analyze the quality management carried out by the two institutions as one of the efforts in the development process of Islamic institutions in Indonesia. The results of this study indicate that both educational institutions have good quality planning and implement the programs well. Those have a direct impact on the quality and development of educational institutions.
\end{abstract}

Keywords. Quality Management, Development, Islamic Education.

Abstrak. Keberadaan lembaga yang berkualitas sangatlah dibutuhkan dalam upaya penyediaan jasa sumber daya manusia (SDM) yang bermutu dan professional. Kebutuhan tersebut tidak akan tercapai kecuali melalui lembaga pendidikan yang bermutu. Diharapkan dari hasil proses pendidikan yang bermutu dapat melahirkan sumber daya manusia (SDM) yang kompetitif baik secara nasional, regional maupun global. Diantara indikasi lembaga pendidikan Islam yang bermutu dapat diketahui dari prestasi baik akademik maupun non akademik dan status akreditasi lembaga secara nasional maupun internasional. Penelitian ini bertujuan untuk menganalisis manajemen mutu yang dilakukan oleh lembaga pendidikan sebagai salah satu upaya proses pengembangan mutu pendidikan Islam yang ada di Indonesia. Hasil penelitian ini menunjukkan bahwa lembaga pendidikan telah memiliki perencaaan mutu yang baik dan kemudian mengimpementasikan program-program yang telah ditetapkan sehingga berdampak langsung pada mutu dan pengembangan lembaga pendidikan.

Kata Kunci. Manajemen Mutu, Pengembangan, Pendidikan Islam.

Copyright (C) JMPI: Jurnal Manajemen Pendidikan Islam. All Right Reserved.

This is an open access article under the CC BY-NC-ND license

(http://creativecommons.org/licenses/by-nc-nd/4.0/).

\section{A. PENDAHULUAN}

Dalam permasalahan penyediaan jasa, sumber daya manusia (SDM) yang profesional di bidangnya sangat dibutuhkan. Kebutuhan tersebut tidak akan tercapai kecuali melalui pendidikan yang bermutu. Pendidikan bermutu sangat di butuhkan dalam rangka menyiapkan tenaga atau sumber daya manusia (SDM) yang unggul dan diharapkan dari hasil pendidikan yang bermutu tersebut dapat melahirkan SDM yang kompetitif baik di tingkat nasional, regional maupun global.

Beberapa permasalahan terkait bidang jasa di era millenial ini akan muncul. Permasalah tersebut di antaranya menyangkut masalah kualitas pendidikan. Apabila 
bangsa Indonesia tidak menyiapkan secara sungguh-sungguh dalam meningkatkan sumber daya manusianya, maka secara kompetitif SDM Indonesia akan termarginalkan. Sumber-sumber usaha atau perekonomian yang seharusnya diisi oleh anak bangsa, menjadi termarginalkan dan diisi oleh tenaga-tenaga kerja asing yang memiliki kompetensi lebih tinggi dan dipekerjakan di berbagai sektor industri dan jasa di Indonesia. Karena itulah, diperlukan upaya peningkatan kompetensi sumber daya manusia (SDM) yang standar baik di dalam maupun luar negeri.

Adanya era industri 4.0 ini memiliki makna dan konsekuensi bahwa lulusan sekolah harus memiliki kompetensi yang kompetitif, yaitu lulusan yang memiliki kemampuan kompetitif tinggi pada tingkat dan jenjang tertentu. Kondisi semacam ini menuntut pada lembaga pendidikan terutama sekolah yang berciri khas agama Islam untuk merancang kualitas atau mutu pendidikannya menjadi lebih baik. Jika dihadapkan dengan tantangan masa depan yang ditandai dengan iklim kompetisi yang sangat ketat, maka satu-satunya jalan yang paling efektif bagi bangsa Indonesia adalah mempersiapkan generasi baru (SDM) yang memiliki keunggulan. Paling tidak dibutuhkan suatu model pendidikan yang secara efektif mampu melahirkan tipologi manusia yang diharapkan, yaitu model pendidikan yang mampu mengemban tugas mengejar keahlian yang disyaratkan dalam kompetisi global (Muhadjir, 1995).

Kebutuhan akan pendidikan dan sumber daya manusia yang unggul kompetitif bagi bangsa Indonesia adalah prasyarat mutlak agar bisa menjadi the winner di era pasar tunggal. Keunggulan sumber daya manusia ini pada gilirannya akan menjadi pilar utama atas keunggulan bangsa dalam hal kualitas dan kuantitas segala produk bangsa Indonesia baik masalah ekonomi, bidang jasa, budaya maupun iptek (Hakim, 2015). Beberapa pandangan terkait terwujudnya lembaga pendidikan yang bermutu itulah yang menjadikan beberapa ahli/pengamat pendidikan mengharapkan adanya lembaga pendidikan yang dapat menjawab tantangan global.

Untuk mengatasi kebutuhan akan kualitas pendidikan maka dibutuhkan manajemen mutu dalam pengembangan lembaga pendidikan Islam yang baik, dalam rangka menjawab tantangan global. Manajemen mutu merupakan salah satu upaya yang dilakukan oleh lembaga pendidikan Islam dalam menjalankan fungsi-fungsi manajemen untuk menciptakan pendidikan yang unggul. Sebab lembaga pendidikan tidak dapat dikatakan unggul apabila tidak memiliki mutu yang baik. Mutu yang baik akan diperoleh melalui usaha yang keras dan disertai semangat dan komitmen membangun mutu dari semua personel lembaga pendidikan itu sendiri. Tanpa adanya semangat yang kuat (komitmen) dalam menciptakan mutu yang baik akan menjadikan semua program gagal dilaksanakan.

Tulisan ini berupaya untuk merespon masih rendahnya mutu pendidikan di Indonesia terutama di lembaga pendidikan Islam (LPI). Sekolah atau madrasah merupakan lembaga pendidikan yang diharapkan dapat mencetak sumber daya manusia yang baik dan unggul. Harapan tersebut akan dapat terealisasi manakala lembaga tempat pendidikan tersebut memiliki mutu yang baik pula. Dalam tulisan ini ada tiga hal yang berkaitan dengan manajemen mutu dalam pengembangan pendidikan Islam. Tiga hal tersebut terkait konsep perencanaan mutu, kemudian strategi pencapaian mutu, serta implikasi manajemen mutunya 


\section{B. METODE}

Paradigma penelitian ini menggunakan interpretative atau post positivistik, penelitian ini menggunakan pendekatan kualitatif dengan menggunakan rancangan multisitus. Peneliti berusaha untuk mengumpulkan data dengan latar alamiah (natural setting) untuk memperoleh data yang sesunguhnya sebagai sumber data secara langsung. Penelitian ini dilakukan melalui data primer yang terdiri dari hasil observasi dan wawancara serta ditunjang dengan data sekunder dari dokumen sekolah yang relevan. Adapun latar belakang peneliti mengunakan metode kualitatif karena peneliti berhasrat untuk menguasai dengan rinci dari masalah yang diteliti dan bukan hanya menjelaskan hubungan sebab-akibat seperti umumnya yang dilakukan peneliti kuantitatif (Rahardjo, 2014).

Pada penelitian ini, eksplorasi adalah hal yang pertama kali dilakukan, kemudian menggambarkan, dengan tujuan untuk dapat menerangkan dan memprediksi terhadap sebuah gejala yang berlaku berdasarkan data yang diperoleh dari lapangan (Faisal, 2003). Data primer berupa gambaran kegiatan manajemen mutu dalam rangka pengembangan lembaga pendidikan Islam dianalisis melalui reduksi, penyajian dan verifikasi data dan validitas data dengan menggunakan triangulasi sumber dan triangulasi taknik. Penelitian ini adalah untuk menemukan sebuah konsep, stategi, dan implikasi manajemen mutu dalam mengembangkan lembaga pendidikan Islam yang unggul

\section{HASIL DAN PEMBAHASAN}

\section{Perencanaan Mutu LPI}

Hasil penelitian terkait konsep perencanaan mutu lembaga pendidikan Islam sebagai berikut: a) memiliki lulusan yang unggul dalam bidang IMTAQ, IPTEK dan mampu berkompetisi dalam tingkat internasional, b) mengintegrasikan kurikulum antara kurikulum nasional, kurikulum yayasan, dan kurikulum Cambridge, c) merencanakan gambungan sistem pembelajaran fullday school yang terintegrasi dengan pesantren (integrated boarding school system), d) Merencanakan pembelajaran di lingkungan sekolah yang bersih, indah, nyaman, serta kondusif, e) Memiliki visi misi tujuan dan program sekolah yang selalu diupdate oleh pihak yayasan / kepala sekolah dan jajaran, serta komite sekolah, f) memiliki penjaminan mutu untuk meningkatkan mutu dan mewujudkan mutu lembaga.

Hasil penelitian ini sesuai dengan pendapat Soetopo yang menyatakan bahwa tujuan pendidikan yang akan dicapai harus sudah tergambar secara jelas atau secara operasional, (Soetopo, 2011). Ketika tujuan tidak tergambar dengan jelas akan menyulitkan pelaksanaan pencapaian mutu. Sebaliknya, kejelasan tujuan lembaga pendidikan tergambar jelas akan memudahkan pencapaian mutu dengan baik. Adapaun kendala dan hambatan yang mungkin timbul dari perencanaan mutu harus segera diprediksi dan disiapkan untuk penanggulangannya. Penanggulangan kendala secara langsung akan dapat melancarkan program mutu sekolah baik akademik maupun non akademik. Diantara program mutu perencanaan akademik yaitu proses pembelajaran . Proses pembelajaran di lingkungan sekolah harus direncanakan agar pembelajaran bisa nyaman dan kondusif. Perencanaan juga harus dapat menemukan berbagai alternatif cara atau metode yang dapat dipergunakan untuk mencapai tujuan mutu yang diharapkan. 
Perencanaan mutu lembaga pendidikan tersebut juga sesuai dengan pendapat Mutohar yang menyatakan bahwa lembaga pendidikan Islam harus mampu membuat school plan dalam meningkatkatkan mutu pendidikan Islam, (Mutohar, 2013). Lingkungan yang kondusif dalam proses pendidikan akan sangat membantu tercapainya tujuan pendidikan yang bermutu. Perancangan lingkungan ideal yang diharapkan oleh para stakeholder akan terwujud manakala ada para pemimpin lembaga pendidikan melakukan perencanaan yang matang terkait perancangan lingkungan ideal tersebut. Peningkatan mutu ini, harus dimulai dengan komitmen yang tinggi dari seluruh civitas akademik lembaga pendidikan Islam dan didukung oleh masyarakat pengguna pendidikan itu sendiri. Komitmen dari seluruh stakeholder internal lembaga pendidikan Islam yang tinggi merupakan prasyarat pertama yang harus dilakukan oleh lembaga tersebut dalam mewujudkan pendidikan Islam yang bermutu dan kompetitif.

Konsep perencanaan mutu lembaga pendidikan Islam terealisasi apabila lembaga pendidikan memiliki prakiraan lingkungan Ideal yang hendak dicapai. Konsep ini merupakan cita-cita dari keadaan lingkungan yang akan diciptakan oleh para pemilik lembaga pendidikan. Sebelum para pemilik lembaga pendidikan membuat lembaga mereka selalu merancang kondisi lingkungan yang akan diciptakan pada proses belajar mengajar. Suasana pembelajaran kondusif sangat berdampak pada proses keberhasilan pendidikan peserta didiknya. Kondisi lingkungan yang kondusif perlu direncanakan dengan baik, agar suasana pembelajaran dapat dikondisikan sesuai dengan harapan stakeholder.

Perencanaan lingkungan yang kondusif dan diharapkan ini dalam arti luas, mencakup iklim dan geografis, tempat tinggal, adat istiadat, pengetahuan, pendidikan dan alam. Dengan bahasa lain lingkungan merupakan segala sesuatu yang tampak dan terdapat di dalam alam kehidupan yang senantiasa berkembang. Ia adalah seluruh yang ada, baik manusia maupun benda buatan manusia, atau alam yang bergerak atau tidak bergerak, kejadian-kejadian atau hal-hal yang mempunyai hubungan dengan seseorang (Munardji, 2014). Dalam lembaga pendidikan, lingkungan perlu diciptakan untuk membentuk atmosfir suasana belajar yang mendukung tercapainya tujuan pendidikan yang diharapkan. Kedua lembaga yang telah diteliti memiliki prakiraan lingkungan masing masing yang berbeda.

Perencanaan mutu lembaga pendidikan Islam akan terealisasi manakala ada perencanaan penetapan/strategi untuk mencapai tujuan lembaga. Setelah melakukan perencanaan terkait tujuan dan maksud didirikannya lembaga pendidikan, kemudian merancang suasana pembelajaran yang kondusif/prakiraan lingkungan yang ideal maka langkah selanjutnya adalah bagaimana menetapkan strategi yang akan diambil dalam merealisasikan tujuan dan prakiraan lingkungan ideal tersebut. Penetapan strategi ini sangat urgen apabila dilihat dari persaingan antar lembaga pendidikan yang sangat ketat. Kesalahan dalam pemilihan atau penetapan starategi dalam mencapai tujuan lembaga akan berpengaruh terhadap kekuatan daya saing lembaga pendidikan yang bersangkutan.

Ada beberapa hal yang perlu diperhatikan terkait perencanaan yaitu berkaitan dengan kebutuhan dan harapan stakeholder dan regulasi yang berlaku. Kebutuhan dan harapan stakeholder diketahui dari berbagai proses pengukuran untuk kemudian di lakukan mapping terkait kebutuhan dan harapannya untuk selanjutnya dapat diambil keputusan. Adapun regulasi strategi yang dikembangkan sekolah harus berdasarkan 
berbagai peraturan yang ada. Penyesuaian ini agar sesuai dengan harapan pemerintah yang merupakan salah satu stakeholder pengguna lulusan sekolah/lembaga pendidikan Islam (Muhaimin 2012).

Dalam perencanaan mutu lembaga pendidikan, harus memiliki unit penjaminan mutu. Terdapat lima kegiatan dalam merencanakan sekolah berbasis mutu yaitu: 1) memahami kondisi dan situasi sekolah berdasarkan hasil evaluasi diri sekolah, 2) merumuskan serta menetapkan situasi dan kondisi masa mendatang, 3) menentukan halhal yang perlu dilaksanakan/selenggarakan untuk mencapai tujuan yang diinginkan, 4) Melakukan pemantauan dan penilaian atau evaluasi dalam pelaksanaannya, 5) Dilaksanakan secara sistematis dan berkesinambungan, (Mutohar, 2013). Dengan adanya pengendalian mutu kinerja, secara langsung akan menunjukkan mutu yang diberikan oleh lembaga dapat dijamin. Adanya penjaminan mutu ini stakeholder akan percaya baik stakeholder internal maupun eksternal. Apabila kepala sekolah melakukan kontrol manajerial terhadap mutu kinerja, maka akan berdampak pada kualitas pembelajaran yang diselenggarakan. Dampak ini akan berimbas kepada prestasi yang akan diraih oleh peserta didik.

\section{Strategi Pencapaian Mutu LPI}

Hasil penelitian juga menunjukkan adanya beberapa strategi yang dilakukan untuk pencapaian mutu lembaga pendidikan Islam yaitu:

\section{a. Strategi evaluasi diri sekolah secara rutin}

Strategi evaluasi ini adalah suatu langkah dalam peningkatan mutu lembaga pendidikan Islam. Hal tersebut mirip pendapat dari Sianipar yaitu: langkah nyata dalam meningkatkan mutu lembaga pendidikan tersebut bisa diwujudkan melalui, pertama; pengembangan dan perbaikan kurikulum berbasis kompetensi. Kedua, memperhatikan kondisi kebutuhan-kebutuhan siswa dan masyarakat (student and social needs) yang beragam. Ketiga, sistem evaluasi yang ada hendaknya dirancang dengan berbasis keahlian peserta didik. Keempat, perbaikan sarana dan prasarana pendidikan, pengembangan dan ketersediaan bahan ajar. Kelima, menambah intensitas pelaksanaan pelatihan bagi pendidik dan tenaga kependidikan. Langkah ketiga dan keempat itulah yang digunakan sebagai modal untuk meningkatkan perbaikan mutu dalam segala hal. Terutama perbaikan dalam peningkatan keefektifan pembelajaran dan kondisi sarana prasarana.

Berdasarkan hasil evaluasi diri inilah kepala sekolah membuat perencanaan strategis dalam meningkatkan mutu pendidikannya. Kepala sekolah mengambil kebijakan-kebijakan strategis yang harus di implementasikan agar mutu pendidikan tercapai dengan baik, berdasarkan visi misi yang telah ditetapkan. Kebijakan tersebut hendaklah mengarah pada upaya menggunakan kekuatan untuk meraih peluang dan mengatasi ancaman yang dihadapi sekolah (Mutohar, 2013). Semua itu dilakukan untuk memperoleh pendidikan yang bermutu di sekolah.

\section{b. Strategi komunikasi}

Komunikasi ini dalam ilmu manajemen merupakan sesuatu yang pokok dalam menjalankan manajemen. Komunikasi harus di bangun dalam setiap kegiatan baik kegiatan yang bersifat internal maupun kegiatan yang berdifat eksternal. Komunikasi dalam manajemen tidak boleh ada sumbatan-sumbatan yang menyebabkan komunikasi terganggu. Baik sumbatan yang terjadi karena ada masalah pribadi maupun sumbatan 
yang terjadi karena ada masalah organisasi. Karena jika terjadi sumbatan-sumbatan dalam komunikasi maka praktek manajemen tidak dapat berjalan dengan lancar. Jangankan mutu manajemen yang baik tidak akan terjadi, karena terbentur dengan sumbatan komunikasi.

Komunikasi juga di bahas dalam Manajemen Mutu Terpadu Pendidikan atau biasa disebut dengan Total Quality Management (TQM) yang merupakan sebuah konsep yang berusaha untuk meningkatkan kualitas dan mutu lembaga secara menyeluruh dan berkelanjutan setara dengan sistem manajemen mutu kelas dunia. Dalam penerapannya, TQM menjadikan manajer tingkat puncak sebagai pimpinan sekaligus berperan menjadi guru dan penasehat (berkomunikasi). Selain itu, harus didukung dengan sumber daya manusia yang berkualitas dan diupgrade melalui proses training and development. Agar menimbulkan teamwork yang dapat memudahkan pencapaian tujuan pendidikan, perlu dilakukan komunikasi efektif dan efisien (Suhardan, 2011).

\section{c. Strategi target mutu}

Kepala sekolah setelah menetapkan visi misi berbasis mutu juga berupaya untuk memperoleh mutu sesuai target yang ditetapkan.Visi misi sekolah bukan hanya sebagai slogan atau pajangan di dinding lembaga pendidikan, akan tetapi visi misi merupan pengejawantahan dari keinginan lembaga dalam mewujudkan lembaga pendidikan yang dicita-citakan. Visi misi harus dijadilak landasan untuk membawa lembaga pendidikan kearah perbaikan yang disertai dengan adanya inovasi-inovasi didalamnya. Untuk mewujudkannya visi misi lembaga pendidikan harus didukung dari peran aktif semua warga sekolah baik guru karyawan terlebih lagi kepala sekolah sebagai pimpinan lembaga Pendidikan (Zahroh, 2014).

Kepala sekolah hendaknya memiliki visi dan misi berbasis pada mutu, bukan hanya sekedar pelengkap administrasi pendidikan. Visi secera sederhana dapat diartikan sebagai pandangan, keinginan, cita-cita, harapan, dan impian impian masa depan (Syafaruddin, 2015). Kalau digabung dengan berbasis mutu maka makna visi itu menjadi pandangan, keinginan cita-cita, harapan dan impian masa depan dengan kualitas yang baik atau memuaskan. Sedangkan misi adalah kegiatan yang harus dilaksanakan dalam kaitannya dengan visi pendidikan yaitu dengan memberikan arahan yang jelas baik untuk masa sekarang maupun untuk masa yang akan datang. Hasil penelitian ini sesuai dengan penelitian dari Pratiwi dan Wiyani (2020) yang menjelaskan bahwa visi dan misi madrasah harus memiliki arah yang jelas agar dapat diwujudkan oleh warga madrasah.

\section{d. Strategi kerjasama/team work.}

Kepala sekolah juga menerapkan kerjasama dengan wakil sekolah bidang kurikulum, kesiswaaan, sarana dan prasarana menjalankan tugasnya sesuai tugasnya. Strategi pencapaian mutu lembaga pendidikan Islam dapat dilaksanakan manakala kepala sekolah membentuk teamwork sebagai penggerak mutu. Team work penggerak mutu merupakan sebuah keharusan yang harus dilakukan oleh kepala sekolah. Tidaklah mungkin sebuah pekerjaan besar dilakukan oleh seorang diri, pasti membutuhkan orang lain.

Ada beberapa langkah strategi menurut Crosby dalam meningkatkan mutu yang bisa diaplikasikan dalam dunia pendidikan diantaranya: pertama, menejemen komitmen; kedua, membentuk tim peningkatan mutu (quality improvement team) di atas dasar komitmen. Tugas utama dari tim penjaminan/peningkatan mutu adalah menentukan menganalisis bentuk-bentuk kegagalan dan menentukan solusi dalam peningkatan 
mutu, dan ini mengarah pada langkah ke tiga; ketiga, pengukuran mutu (quality measurement); keempat, menghitung jumlah biaya peningkatan mutu (the cost of quality); kelima, membangun kesadaran mutu; keenam, kegiatan perbaikan. Para pengawas harus bekerjasama dengan para staff untuk memperbaiki mutu yang rendah; ketujuh, perencanaan tanpa cacat (Zero Defect Planning) (Riyadi, 2001).

Pendapat Crosby yang kedua tersebut merupakan langkah dalam memperoleh lembaga pendididkan yang bermutu. Tanpa danya kerjasama dalam team work lembaga pendidikan akan sulit mencapai mutu yang diharapkan. Sehingga dengan demikian hasil penelitian yang menyatakan bahwa keberhasilan mutu itu dilatarbelakangi diantaranya dengan komitmen pemimpin yang kuat dan adanya kerjasama dalam team work oleh Crosby di dalam teorinya. Apabila dihadapkan dengan teori yang sudah dikemukakan Edward Sallis (2011) banyaknya sumber daya belum bisa dijadikan ukuran untuk perbaikan mutu, karena perbaikan mutu memerlukan tim khusus. Sedangkan apabila dihadapkan dengan teori dari Crosby, temuan penelitian ini memiliki kesamaan dalam segi pembentukan Team Work penjaminan atau perbaikan mutu. Hasil ini juga sama dengan penelitian Dewi dan Ali (2020) yang menjelaskan bahwa komitmen dan keterlibatan semua unsur di dalam sekolah diperlukan untuk meningkatkan mutu sekolah tersebut.

\section{e. Strategi penerapan budaya mutu.}

Strategi ini diterapkan agar terbentuk kesadaran warga sekolah untuk peningkatan mutu lembaga. Strategi ini merupakan bentuk dari adanya komitmen yang dibangun oleh kepala sekolah dalam lembaganya. Peneliti menemukan dikedua lembaga tersebut sama-sama memiliki komitmen yang tinggi terhadap perbaikan mutu. Karena kunci perbaikan mutu terletak pada komintmen yang dimiliki oleh semua civitas akademika terutama pada pimpinannya. Pemimpin adalah orang yang memiliki tanggung jawab dalam proses perbaikan dalam setiap lembaga, (Syafaruddin, 2001). Ada beberapa faktor yang telah diidentifikasi oleh E. Sallis (2011) agar menjadi baik, diantaranya; (1) kepemimpinan yang kuat dan berorientasi pada mutu, (2) SDM yang berlimpah, (3) dukungan orang tua dan semua elemen masyarakat, (4) tenaga pendidik dan kependidikan yang unggul dan berkarakter, (5) penggunaan teknologi yang mutakhir, (6) sistem nilai yang kokoh, (7) sarana dan prasarana yang memadai serta desain kurikulum yang mendeskripsikan arah visi misi pendidikan yang ingin dicapai. Pendapat E. Sallis yang pertama yaitu kepemimpinan yang kuat dan berorientasi terhadap mutu inilah yang menjadikan kedua sekolah tersebut dapat mendukung terlaksananya lembaga Pendidikan yang bermutu.

Strategi target mutu ini menurut E. Sallis, merupakan faktor penting dalam menciptakan lembaga pendidikan yang bermutu. Factor pertama tersebut adalah pemimpin yang akan menentukan baik dan tidaknya sebuah lembaga pendidikan. Walaupun begitu tidak kemudian mengkesampingkan yang lain, seperti guru karyawan dan semua sivitas akademik yang terlibat didalamnya. Para guru dan karyawan serta siswa semuanya merupakan input Pendidikan yang diharapkan memiliki mutu yang baik. Tinggi rendahnya mutu input merupakan hasil pengukukuran tingkat kesiapan input. Makin tinggi tingkat kesiapan input dalam mengembangkan lembaga pendidikan maka, makin tinggi pula mutu input tersebut. (Diknas, 2002) Adanya komitmen kepala sekolah untuk mencapai target mutu yang tinggi akan membantu terciptanya lembaga yang berkualitas. 
Visi merupakan statement yang mendeskripsikan tujuan umum dari sebuah institusi dan untuk apa visi itu dicapai (Sallis, 2011). Visi misi merupakan aspek yang harus diperhatikan dalam proses pendidikan. Visi yang dirancang dengan matang, beserta tahapan pelaksanaan dalam misi akan menghasilkan pendidikan yang bermutu. Keberhasilan suatu visi dan misi pada hakikatnya terletap pada peran aktif seluruh pihak sekolah terutama kepala sekolah. Tanpa peran aktif dari seluruh civitas sekolah maka akan sulit terwujud dan hanya ada dalam angan angan saja (Zahroh 2014).

\section{Implikasi Manajemen Mutu LPI}

Pertama, hasil penelitian terkait implikasi yang diperoleh kedua lembaga tersebut yaitu: 1) meningkatan etos kerja tenaga pendidik dan kependidikan, 2) Terbentuknya rasa tanggunggjawab yang tinggi yang dapat memunculkan komitmen yang kuat untuk meningkatkan mutu lembaga, 3) Tersedianya pelayanan publik yang ramah, bersih, dan berbasis IT, 4) Peningkatan pedagogik dan kompetensi tenaga pendidik. 5) Peningkatan jumlah lulusan yang masuk perguruan tinggi baik dalam negeri ataupun luar negeri. 6) Peningkatan prestasi akademik dan non akademik siswa dari tahun ke tahun. 7) Terciptanya suasana belajar yang kondusif dengan adanya peningkatan sarana prasarana untuk menunjang kegiatan belajar mengajar. 8) Terpenuhinya fasilitas sekolah yang sangat memadai. 9) Adanya dukungan dari stakeholder dan masyarakat terkait mutu lembaga. 10) Pelayanan kesehatan yang memadai untuk meningkatan standar hidup sehat bagi warga sekolah.

Tujuan hubungan antara lembaga pendidikan Islam dengan masyarakat ditinjau dari kepentingan lembaga pendidikan Islam adalah; 1) Memelihara kelangsungan hidup lembaga pendidikan Islam, 2) Meningkatkan mutu lembaga pendidikan Islam, 3) Memperlancar proses belajar mengajar, 4) Memperoleh dukungan dan bantuan dari masyarakat yang diperlukan dalam pengembangan (Baharuddin, 2012).

Dalam kajian teori penelitian ini, keempat indikasi tujuan hubungan antara lembaga pendididkan Islam dengan masyarakat ini sama dengan implikasi pelaksanaan manajemen mutu ketika manajemen mutu dijalankan. Yaitu: pertama, terpeliharanya kelangsungan hidup lembaga pendidikan Islam, ini tergambar pada hasil penelitian bahwa dikedua lembaga pendidikan Islam tersebut terdapat adanya suasana belajar yang kondusif dengan adanya peningkatan sarana prasarana untuk menunjang kegiatan belajar mengajar. Tidak mungkin suasana yang kondusif serta peningkatan sarana prasarana dalam menunjang kegiatan belajar mengajar terjadi tanpa adanya terpeliharanya kelangsungan hidup sebuah lembaga. Terlebih lagi jika terdapat terpenuhinya fasilitas sekolah yang sangat memadai. Semua ini menunjukkan adanya terpeliharanya kelangsungan hidup lembaga pendidikan Islam.

Kedua, meningkatkan mutu lembaga pendidikan Islam, ini tergambar dari adanya peningkatan etos kerja tenaga pendidik dan kependidikan, terbentuknya rasa tanggunggjawab yang tinggi yang dapat memunculkan komitmen yang kuat untuk meningkatkan mutu lembaga, tersedianya pelayanan publik yang ramah, bersih, dan berbasis IT. dan peningkatan jumlah lulusan yang masuk perguruan tinggi baik dalam negeri ataupun luar negeri. Sedangkan yang ketiga adalah Memperlancar proses belajar mengajar ini juga ditunjukkan dari adanya peningkatan pedagogik dan kompetensi tenaga pendidik. Sedangkan yang keempat yaitu mendapat dukungan serta bantuan dari pihak pengguna yang diperlukan dalam pengembangan, ini tergambar dari adanya 
dukungan dari stakeholder dan masyarakat terkait mutu lembaga. Dan adanya pelayanan kesehatan yang memadai untuk meningkatan standar hidup sehat bagi warga sekolah.

Sedangkan jika ditinjau dari kebutuhan masyarakat akan pendidikan yang bermutu yaitu: 1) Memajukan dan meningkatkan kesejahteraan masyarakat terutama dalam bidang mental spiritual, 2) Memperoleh bantuan dari lembaga pendidikan Islam terutama dalam memecahkan berbagai masalah yang dihadapi oleh masyarakat, 3) Menjamin relevansi program lembaga pendidikan Islam dengan kebutuhan masyarakat, 4) Memperoleh kembali anggota-anggota masyarakat yang makin meningkat kemampuannya (Baharuddin, 2012). Dalam hal ini memang peneliti hanya membahas implikasi dari pelaksanaan manajemen mutu bukan manfaat kebutuhan masyarakat akan pendidikan yang bermutu. Sehingga berbeda dalam segi cara pandang mutu manfaat mutu bagi masyarakat dan manfaat mutu bagi lembaga pendidikan Islam. Kalaupun disamakan implikasi manajemen mutu pada masyarakat itupun hanya adanya peningkatan jumlah lulusan yang masuk perguruan tinggi. Manfaat kepada pihak pengguna sekolah atau masyarakat memperoleh kembali anggota-anggota masyarakat yang makin berkualitas.

Implikasi pelaksanaan manajemen mutu dalam lembaga pendidikan Islam diantaranya: Adanya dukungan dari stakeholder dan masyarakat terkait mutu lembaga. Hal ini dilakukan untuk memperoleh dukungan positif dari masyarakat, lembaga pendidikan Islam harus memiliki hubungan yang baik (habluminannas) dengan masyarakat yang ada di lingkungan sekitar sekolah. Komunikasi yang baik dan benar (komunikatif), dapat memberikan perubahan sikap, padangan atau pendapat, dan kehidupan sosial seseorang (Saefullah, 2012). Dengan komunikasi yang baik secara internal dan eksternal, lembaga pendidikan akan dapat membangun hubungan yang harmonis antara lembaga dengan masyarakat yang ada di lingkungan sekitar lembaga. Implikasi peningkatan manajemen mutu dikedua lembaga pendidikan tersebut sudah tampak berjalan dengan baik. Hubungan yang baik ini dapat diketahui dari data yang menunjukkan kerjasama antara lembaga pendidikan dengan masyarakat sekitar sekolah.

Tujuan pengelolaan lembaga pendidikan Islam adalah untuk meningkatkan efesiensi dan efektifitas kerja dan pencapaian tujuan lembaga secara keseluruhan. Yaitu: 1) meningkatnya keharmonisan hubungan kerja antara pemimpin dengan staf lembaga, 2) meningkatnya kemampuan memecahkan persoalan lembaga secara lebih terbuka dan peningkatan keterbukaan dalam komunikasi, 3) peningkatan semangat kerja para anggota lembaga, 4) kemampuan mengendalikan diri sendiri (Baharuddin, 2012). Dalam penelitian ini, implikasi dari pelaksanaan manajemen mutu tidak jauh berbeda dengan tujuan pengelolaan lembaga pendidikan Islam di atas. Seperti: meningkatnya keharmonisan hubungan kerja antara pemimpin dengan staf lembaga, dan peningkatan semangat kerja para anggota lembaga. Hal ini di tunjukkan dengan adanya peningkatan etos kerja tenaga pendidik dan kependidikan, sedangkan meningkatnya kemampuan memecahkan persoalan lembaga secara lebih terbuka dan peningkatan keterbukaan dalam komunikasi ini ditunjukkan dengan adanya rasa tanggung jawab yang tinggi yang dapat memunculkan komitmen yang kuat untuk meningkatkan mutu lembaga.

Dalam pengembangan madrasah menuju sekolah Islam yang modern dapat dibuktikan dari beberapa indikator yaitu: 1) sangat mudah dalam mengadakan evaluasi, 2) mutu madrasah yang semakin meningkat, 3) Permintaan siswa baru setiap tahun 
meningkat, 4) pembinaan dan kedisiplinan guru yang semakin meningkat, 5) kesejahteraan guru dan karyawan yang semakin meningkat, 6) kepercayaan dan partisipasi masyarakat /orangtua semakin meningkat, 7) pembangunan sarana prasarana yang semakin meningkat (Baharuddin, 2012).

Beberapa indikator tersebut juga terdapat dalam implikasi manajemen mutu dalam meningkatkan lembaga pendidikan Islam. Seperti sangat mudah dalam mengadakan evaluasi ini ditunjukkan dari adanya meningkatannya etos kerja tenaga pendidik dan kependidikan, tidak mungkin adanya peningkatan etos kerja tanpa adanya evaluasi kerja yang selama ini dilakukan. Yang kedua misalnya mutu madrasah yang semakin meningkat, ini ditunjukkan dari adanya peningkatan jumlah lulusan yang masuk perguruan tinggi baik dalam negeri ataupun luar negeri. Kesejahteraan guru dan karyawan yang semakin meningkat ini ditunjukkan dari adanya pelayanan kesehatan yang memadai untuk meningkatan standar hidup sehat bagi warga sekolah. Seperti juga kepercayaan dan partisipasi masyarakat /orangtua semakin meningkat ini juga ditunjukkan dari adanya dukungan dari stakeholder dan masyarakat terkait mutu lembaga.

Implikasi pelaksanaan manajemen mutu ini berkaitan juga dengan pembentukan madrasah yang efektif. Madrasah yang efektif mempunyai karakteristik sebagai berikut: 1) Proses belajar mengajar mempunyai efektifitas yang tinggi, 2) Kepemimpinan madrasah yang kuat, 3) Lingkungan madrasah yang aman dan tertib, 4) Pengelolaan tenaga pendidik yang efektif, 5) Memiliki budaya mutu 6) Memiliki team work yang kompak, cerdas, dan dinamis, 7) Memiliki kewenangan kemandirian, 8) Partisipasi yang tinggi dari warga madrasah, 9) Memiliki keterbukaan (transparasi) manajemen, 10) Memiliki kemauan untuk berubah (baik secara psikologis dan fisik), 11) Melakukan evaluasi dan perbaikan secara berkelanjutan, 12) Responsive dan antisipatif terhadap kebutuhan, 13) Memiliki komunikasi yang baik, 14) Memiliki akuntabilitas, 15) Memiliki kemampuan menjaga sustainabilitas (Mutohar, 2013).

Ada perbedaan yang mencolok antara karakteristik sekolah efektif dengan implikasi manajemen mutu dalam penelitian ini. Perbedaan ini sesebabkan karena sudut pandang implikasi dengan karakteristik yang muncul. Walaupun sebenarnya ada juga persamaannya yang muncul seperti: Proses belajar mengajar mempunyai efektifitas yang tinggi, ini ditunjukkan dari adanya terciptanya suasana belajar yang kondusif dengan adanya peningkatan sarana prasarana untuk menunjang kegiatan belajar mengajar. Ada juga kepemimpinan madrasah yang kuat ini juga diitunjukkan dari adanya meningkatan etos kerja tenaga pendidik dan kependidikan, ada juga lingkungan madrasah yang aman dan tertib, ini ditunjukkan dengan tersedianya pelayanan publik yang ramah, bersih, dan berbasis IT. Temuan tersebut memiliki kesamaan dengan teori implikasi yang dikemukakan oleh Baharuddin dalam hal memelihara kelangsungan hidup, meningkatkan mutu lembaga pendidikan Islam, memberikan kelancaran dalam proses belajar mengajar dan memperoleh dukungan dan bantuan dari masyarakat yang diperlukan dalam pengambangan serta pelaksanakan program yang diselenggarakan lembaga pendidikan Islam.

\section{KESIMPULAN}

Lembaga pendidikan yang bermutu merupakan lembaga pendidikan yang memiliki perencanaan dan strategi pencapaian mutu yang baik. Konsep perencanaan 
mutu pengembangan LPI adalah dengan; a) merancang lulusan yang unggul baik dalam bidang IMTAQ, IPTEK dan mampu berkompetisi dalam tingkat internasional, b) memiliki kurikulum yang terintegrasi antara kurikulum nasional, kurikulum yayasan, dan kurikulum Cambridge, c) memiliki system pembelajaran fullday school yang terintegrasi dengan pesantren atau bisa disebut dengan system boarding school, d) menciptakan pembelajaran di lingkungan sekolah yang bersih, indah, nyaman, serta kondusif, e) memiliki visi misi tujuan dan program sekolah yang selalu diupdate oleh pihak yayasan/kepala sekolah dan jajaran, serta komite sekolah, f) memiliki unit penjaminan mutu untuk meningkatkan mutu dan mewujudkan mutu lembaga.

Strategi pencapaian mutu pengembangan LPI yaitu: a) menerapkan strategi evaluasi diri sekolah secara rutin untuk memantau keefektifan pembelajaran termasuk kondisi sarana prasarana, b) menerapkan strategi komunikasi dalam lingkup civitas yayasan dan lembaga terutama pada musyawarah juga stakeholder, c) menerapkan strategi bimbingan belajar yaitu memberikan jam intensif pendalam materi/pelajaran kepada peserta didik dalam menghadapi Ujian Nasional (UN) dan persiapan masuk perguruan tinggi favorit, d) kepala sekolah sebagai eksekutor visi dan misi, tujuan dan terget sekolah dengan membuat standar pelaksanaan mutu dengan menggunakan strategi terget mutu berupa akreditasi, ISO termasuk setoran hafalan Quran, e) wakil sekolah bidang kurikulum, kesiswaaan, sarana dan prasarana menjalankan tugasnya sesuai tugasnya yaitu menggunakan strategi kerjasama, f) penerapan strategi tauladan budaya mutu agar terbentuk kesadaran warga sekolah untuk peningkatan mutu lembaga, g) menerapkan strategi pendelegasian dengan membentuk teamwork agar terbentuk komitmen tersebut dalam bentuk peningkatan program-program yang bermutu.

Implikasi manajemen mutu pengembangan LPI yaitu: a) peningkatan etos kerja tenaga pendidik dan pendidikan, b) terbentuknya rasa tanggunggjawab yang tinggi yang dapat memunculkan komitmen yang kuat untuk meningkatkan mutu lembaga, c) tersedianya pelayanan publik yang ramah, bersih, dan berbasis IT, d) peningkatan pedagogik dan kompetensi tenaga kependidikan, e) peningkatan jumlah lulusan yang masuk perguruan tinggi baik dalam negeri ataupun luar negeri, f) peningkatan prestasi akademik dan non akademik siswa dari tahun ke tahun, g) terciptanya suasana belajar yang kondusif dengan adanya peningkatan sarana prasarana untuk menunjang kegiatan belajar mengajar, h) terpenuhinya fasilitas sekolah yang sangat memadai. i) adanya dukungan dari stakeholder dan masyarakat terkait mutu lembaga, j) pelayanan kesehatan yang memadai untuk meningkatan standar hidup sehat bagi warga sekolah.

\section{REFERENSI}

Baharuddin. (2012). Pengembangan Lembaga Pendidikan Islam. Malang: UIN Press.

Departemen Pendidikan Nasional. (2002). Manajemen Peningkatan Mutu Berbasis Sekolah. Jakarta.

Dewi, P. R., \& Ali, N. (2020). Peningkatan Skor Akreditasi Madrasah melalui Lembaga Penjaminan Mutu. J-MPI (Jurnal Manajemen Pendidikan Islam), 5(1), 44-54. https:// doi.org/10.18860/jmpi.v5i1.9046

Faisal, Sanapiah. (2003). Format-Format Penelitian. Jakarta: Raja Grafindo Persada. Hakim, Dhikrul. (2015). Makna Strategi Pendidikan Unggul Menyongsong Pasar Tunggal Asean 2015. Prosiding Seminas Competitive Advantage, Vol 1, No 1. 
Muhaimin. Dkk. (2012). Manajemen Pendidikan Aplikasi Dalam Rencana Pengembangan Sekolah/Madrasah. Jakarta: Kencana.

Munardji. (2004). Ilmu Pendidikan Islam. Tulungagung: PT. Bina Ilmu.

Muhadjir, Noeng. (1995). "Problematika pendidikan menghadapi tantangan tahun 2020" Makalah, disajikan pada Seminar HIPISS Cabang Yogyakarta tanggal 24 Oktober (Yogyakarta: Universitas Gajah Mada, 1995)

Mutohar, Prim Masrokan. (2013). Manajemen Mutu Sekolah. Jogjakarta: ArRus Media.

Pratiwi, Y. A., \& Wiyani, N. A. (2020). Kepemimpinan Visioner Dalam Implementasi Program Full Day School Di Madrasah Ibtidaiyah. J-MPI (Jurnal Manajemen Pendidikan Islam), 5(2), 98-111. https:// doi.org/10.18860/jmpi.v5i2.10387

Rahardjo, Mudjia. (2014). Mengenal Lebih Jauh Tentang Studikasus. materi kuliah S3 MPI UIN Malang.

Riyadi, Ahmad ali dan fahrurrozi. (2001). Total Quality Management in Education. Jogjakarta: IRCiSoD.

Saefullah, U. (2012). Manajemen Pendidikan Islam. Bandung: CV Pustaka Setia.

Sallis, Edward. (2011). Manajemen Mutu Terpadu Pendidikan. Jogjakarta: IRCiSoD

Siagian, Sondang P. (2002). Kiat Meningkatkan Produktifitas Kerja. Jakarta: PT. Rineka Cipta.

Soetopo, Hendiyat. (2001) Manajemenen Pendidikan. Malang: Program Pascasarjana Universitas Negeri Malang.

Suhardan, Dadang dkk. (2011) Manajemen Pendidikan. Bandung: ALFABETA.

Syafaruddin. (2015). Manajemen Lembaga Pendidikan Islam. Jakarta: Ciputat Press.

Syafaruddin. (2001). Manajemen Mutu Terpadu Dalam Pendidikan. Jakarta: PT Gramedia Widiasarana Indonesia.

Zahroh, Aminatul. (2014). Total Quality Management. Yogyakarta: Ar Ruzz Media. 